\title{
Understanding Humanistic Management
}

\author{
Domenec Melé ${ }^{1}$
}

Received: 12 March 2016/Accepted: 23 April 2016/Published online: 3 August 2016

(C) Springer International Publishing 2016

\begin{abstract}
Humanistic management is a people-oriented management that seeks profits for human ends. It contrasts with other types of management that are essentially oriented toward profits, with people seen as mere resources to serve this goal. This article reviews the historical development of humanistic management and the ever-increasing body of literature on the concept as well as the different meanings that scholars attribute to it. It then explores what form a genuine humanism might have by presenting seven propositions labeled as: 1) wholeness, 2) comprehensive knowledge, 3) human dignity, 4) development, 5) common good, 6) transcendence, and 7) stewardship-sustainability. Next, it looks at four characteristics of a humanistic ethos for managing business: the view of the individual and human work, the role of the individual in the society and in interacting with nature, the business firm, and the purpose of business in society. Finally, it presents some insights for the practice of humanistic management.
\end{abstract}

Keywords Humanism $\cdot$ Human dignity $\cdot$ Human flourishing $\cdot$ Humanistic management

\section{Introduction}

Humanistic Management (HM), understood in a very broad sense, regards concern for persons and human aspects in managing organizations. It is oriented not only to obtaining results through people, but also, and above all, toward people themselves, showing care for their flourishing and well-being.

As we will discuss below, some have discussed HM by introducing human psychology in management, or by seeing the centrality of people as essential for a successful business management. Others, appeal for a shift in the mainstream economistic paradigm and the placing of human persons and their flourishing and well-being as the fundamental management orientation. The latter view underlies the Humanistic Management Movement which emerged in the first decade of the 21 st century, with significant precedents in the last

Domenec Melé

DMele@iese.edu

1 IESE Business School, University of Navarra, Barcelona, Spain 
third of the 20th century. This movement has gained momentum since 2010, and an increasing number of scholars and business executives are showing interest in HM.

Although many would probably agree with the broad basic description of HM given at the beginning of this article as concern for persons and human aspects in managing organizations, this is too generic. Thus, a question arises: what do scholars mean by humanistic management? Our first aim here is to explore this very question. To this end, we will start by presenting a brief review of the historical development of ideas on HM, and then discuss the meaning of the concept as seen by several relevant scholars.

A second question which we will also try to answer is of what features might characterize a genuine humanism and how this can be applied to HM. After presenting a set of proposition to describe humanism, we will outline four key elements of a humanistic ethos for business management and present some insights for the practice of humanistic management.

\section{The Historical Development of Humanistic Management}

\section{Humanistic Management as an Alternative to "Mechanistic" Management}

As an antecedent of the current movement of HM we might mention some scholars of management thought who focus more on people than on techniques in management. In the first decades of management thought, many authors defended the importance of the human side of management -even without using the expression "humanistic management". Some emphasized the importance of human needs and motivations (Maslow, McGregor, Herzberg, Lickert, Bennis, and others), while others presented a vision of management which did not separate the technical and human aspects or which stressed the centrality of persons (Follett, Barnard, Drucker). Thus, Mary Parker Follett, a very well-known pioneer in management studies, once wrote: "We can never wholly separate the human and the mechanical problem. (...) But you all see every day that the study of human relations in business and the study of technique of operating are bound up together.” (1941[1925], p. 124). Chester I. Barnard, on his part, highlighted the importance of cooperation in business and the responsibility of the manager to respect people and to promote cooperation between them (Wolf 1974). Peter Drucker, the great guru of management, argued that management is about people, stressing the importance of the wholeness of the person - along with power, values, structure and responsibilities (Linkletter and Maciariello 2011; Maciariello 2014).

The first time the terms humanistic and management appeared together was very possibly in a book published in 1967 and authored by David E. Lilienthal with the title Management: A Humanistic Art (Lilienthal 1967). The vision of this book is that management is not science but art. This contrasts with the scientific management, proposed by Taylor (1911) and other mainstream "mechanistic" approaches, quite popular at that time. Lilienthal did not deny the importance of techniques and skills in management but stressed that managers should understand individuals and their motivations and help them to achieve their goals. Following the ideas of the so-called "Human Relations School", Lilienthal defended the idea that the manager is essentially a motivator of and facilitator for others. He accented the uniqueness of each employee, the singularity of every situation and the necessity of managing "like an artist" rather than using a set of learned guidelines.

Swart (1973) used the term "humanistic management" to refer to a set of innovative proposals made at the time to overcome the monotonous repetition of tasks established by 
scientific management to improve productivity, but with no thought given to worker motivation. He affirmed: "Humanistic management, often called job enrichment, is a new way to cope with old problems -motivation, work satisfaction, morale, and productivity." (Swart 1973, p. 41) Drawing from Herzberg (1968), this scholar suggested that HM involves giving employees more responsibilities and variety in their jobs in order to motivate them and increase their satisfaction and productivity.

In the mid-1980s, and interpreting what might then have been a common understanding of HM, Daley observed: "humanistic management is regarded by many as a means for both productivity and for developing human potential." (1986, p. 131) In his research, Daley (1986) uses several "humanistic" characteristics related to dealing with people in the production process as indicators, including job challenge, role clarity, performance appraisal fairness (job design and performance appraisal), personal significance, supervisory relationship and employee freedom (work environment).

In more recent times, several authors, even without presenting themselves as advocates of $\mathrm{HM}$, have insisted on the centrality of people within the organization and on considering the human being as a whole. To mention a few, Plas (1996) proposed a person-centered leadership in which participation is essential. Ghoshal and Bartlett (1997) focused on people-centered policies, corporate purpose and culture instead of the conventional "industrial machine"; beyond the traditional rigidity of structures and system, they proposed creating "organizations of individuals" where, in addition to pursuing results, organizations could be a forum for human interaction and personal fulfillment. On his part, Pfeffer (1998) suggested putting people first to achieve organizational success.

\section{Humanizing Business}

From an ethical perspective, a number of voices have advocated a humanizing of business. One of the first to do so was Pope Leo XIII in the late 19th century. He condemned situations in workshops and factories where "employers laid unjust burdens upon their workmen "or degraded them with conditions repugnant to their dignity as human beings." (Leo XIII 1891, n. 36) In positive terms, he exhorted employers "to respect in every man his dignity as a person" (Leo XIII 1891, n. 20). Several documents of Catholic social teaching have continued in the same line (see a compendium of the 20th century in PCJP 2004)

The United Nations and other international organizations have also called for business to be more ethical and humane. Focusing on work, the International Labor Organization has promoted numerous conventions to humanize human work in the business context.

Since the mid-1970s, several scholars of management have championed the humanizing of business. Among others, Mire (1976) proposed humanizing the workplace and Meltzer and Wickert (1976) focused on humanizing organizational behavior. Cunningham and Tichy (1983) supported reforms within the corporate community, including changes in relationships, attitudes and business methods that influence and shape the lives of human beings through corporate culture. French and Bell (1984) pointed out the need to introduce humanistic values in organizational development. They emphasized the importance of individuals, respect for freedom and the importance of avoiding the misuse of power. Anderson (1997) suggested a "values-based management" and Argandoña (2003) discussed how to foster values in organizations.

In the late 1970s, the business ethics movement emerged (De George 2006), calling for humanizing business as well as promoting integrity in management. Humanism and business ethics should go together, if accept that ethics is "rooted in our humanity" (Kleinfeld et al. 
2003, p. 1). This idea is not new -it is essential in Aristotle and Aquinas, for instance-, but it has not always been sufficiently valued. Among those in favor of this approach are Dierksmeier et al. (2011) who have discussed the concept of "humanistic ethics" in the context of a global world.

\section{Humanism in Economics and Business}

Lutz and Lux $(1979,1988)$ proposed shifting the perspective in economics, and proposed what they termed "Humanistic Economics", based on a new and more accurate vision of the person in economic theory. They made the observation that " $[\mathrm{t}] \mathrm{his}$ [old] theory is an inheritance largely from eighteenth and nineteenth century British philosophy, with its hedonistic mechanical, and narrow image of the person." (Lutz and Lux 1988, p. 1). Facing a mainstream economics based on self-interest as the only motive for acting, they do not deny that people seek personal advantage, but add, "if there is another side to human nature that operates alongside the selfinterest side, then to reduce the human being to only the former is to distort the reality." (Lutz and Lux 1988, p. 18). In this line of thought, they proposed a vision of humanistic economics which "aims for a more complete image of the person." (Ibid.) In their own words, "We need an economics with an uplifting and constructive vision, an economics allowing us live fully" (Lutz and Lux 1988, p. 1). On one hand, we need an economics which works, an economics, which "can physically maintain and sustain us", but on the other hand, "we also need an economics that is ennobling, that we can be proud to identify with and proclaim." (Lutz and Lux 1988, p. 1).

From a different and more radical perspective, Aktouf (1992) argued for a shift in the current paradigm of business. He criticized the currently-dominant and even innovative management approaches for being based on the functionalistic tradition. "Most proponents of the new management trends-he wrote-focus current discussions and concerns on the employee (human capital and resource). This is a sure sign of rekindled interest in the human element. However, by implicitly maintaining the status quo in all that concerns power, control of profits, and the division of labor, the new trend is a false and stunted humanism." (Aktouf 1992, p. 412). As an alternative, he defended a radical-humanistic conceptualization of organizations and suggested a proposal based on the neo-Marxist humanism, which entails a global view of humankind and emphasizes the concept of alienation. In his view, management theorists and practitioners should integrate such a concept in order to better understand how to transform the passive/obedient Taylorist employee into an active-cooperative one. This Marxist-based radical humanism, at the center of which is not the individual but humankind, may be criticized (Gómez Pérez 1977, pp. 185ff), but his observation regarding the limited humanism of those who see human beings only as human capital or resources seems quite valid.

Ghoshal, Bartlett, and Moran (1999) launched “A New Manifesto for Management” in which they argued for a management focused on creating value for the society and for people. Concern for humanizing the firm and the management profession can also be found in several scholars, included in a book edited by Ricart and Rosanas (2012). In addition, Andreu and Rosanas (2012) launched a "Manifesto for a Better Management" which adopted a rational and humanistic view.

\section{The Humanistic Management Movement}

In 1986, a permanent seminar to integrate humanism in business was established at the University of Navarra, Spain, which soon became the "Business and Humanism Institute" 
(see some relevant contributions in Llano et al. 1992). In the early years the scholars of this institute rarely talked explicitly of "humanistic management" but a humanistic vision in managing business was continuously present in their writings and speeches. Thus, according to Alvira (1992), entrepreneurs and managers should have the broad vision that the humanists had, "because the product or service that [the businessperson] performs is a function of the social whole" (Alvira 1992, p. 38). He also stressed that humanism in business is something beyond business ethics (Alvira 1992, p. 40), at least, if this discipline was limited, as noted above, to solving ethical dilemmas or reasoning on ethical issues in business.

At the beginning of this century, humanistic management was presented as a "real challenge to achieving a higher ethical quality in management." (Melé 2003a, p. 85) and a need for good management (Rosanas 2008). In 2009, the book Humanism in Business, edited by Spitzeck et al. (2009), brought together a number of scholars with an interest in a human-centered management. This book questions some proposals then current in the field of business and society, such as stakeholder participation, corporate social responsibility, and corporate philanthropy, although accepting that they do a humanistic aspect. By way of an alternative, the editors of the book affirm that it "investigates the possibility of creating a human-centered, value-oriented society based on humanistic principles" (Spitzeck et al. 2009, Foreword). They not only defend humanism in business, but also try to show "how humanism can be used to understand, and possibly transform, business at three different levels: the systemic level, the organizational level, the individual level” (Ibid.). Heiko Spitzeck, Michael Pirson, Wolfgang Amann, Shiban Khan and Ernest von Kimakowitz, editors of the book, along with Claus Dierksmeier, were the core of Humanistic Management Network (HMN) which emerged late in the first decade of this century. The HMN was presented by Spitzeck et al. (2010) in the journal Zeitschrift für Psychologie.

HMN has become visible mainly through a website (www.humanetwork.org), which publicizes and promotes different activities of the network, including symposia and caucus in the Academy of Management, specific conferences or panels as a part of other conferences, research papers and a book series published by Palgrave-MacMillan (Humanism in Business Series). In this website, HMN is presented as "an international, interdisciplinary, and independent network that promotes the development of an economic system with respect for human dignity and well-being". Its mission is "to foster the creation and dissemination of actionable knowledge to change business practices towards humanistic ideals, and to influence business academia, management practitioners, policy makers, and the general public in defining the purpose and role of business in a global society." (website of HMN).

Another contribution to the humanistic management movement has come from Christian social thought, with individual contributions (e.g., Zigarelli 1993; Cima and Schubeck 2001; Abela 2001; Cornwall and Naughton 2003; Bainbridge 2003; Clark 2004; Sandelands 2009; Tablan 2014), conferences, such as the International Symposia on Catholic Social Thought and Management Education (since 1996) and the Colloquia on Christian Humanism in Economics and Business (since 2010), books and edited books (Alford and Naugthon 2001; Cortright and Naugthon 2002; Melé and Dierksmeier 2012; Abela 2014, Melé and Schlag 2015), and special issues of journals (Journal of Business Ethics, 2012, Vol. 100, n. 1; Journal of Business Ethics, 2016, forthcoming).

In the last decate years an increasing number of scholars have published articles in referred journals and books; among these, Arnaud (2008), Amann et al. (2011), Melé (2009, 2012, 2013), Kimakowitz et al. (2011b), Rocha and Miles 2009; Dierksmeier and Pirson (2010), Dierksmeier et al. (2011), Acevedo (2012), Beaudreau (2012), Spitzeck (2011), Pirson and Kimakowitz (2014), Lupton and Pirson (2014), Arnaud and Wasieleski (2014), Arandia and Portales (2015). 


\section{What Do Scholars Mean by Humanistic Management?}

As noted above, the first use of the concept "humanistic management" refers to taking into consideration a variety of human capacities and fostering them to contribute to a better performance. The vision of the human being in this primitive HM rejects reductionist views such as that of the homo economicus of the neo-classical economic theory -seen exclusively as a being with preferences and rationality to maximize the achievement of these preferences- or the homo mechanicus of Taylor's scientific management -limited to executing strict and detailed orders of managers. In the new approach the human being is both rational and emotional and, in addition, considers it that individuals have talents and creativity, and therefore the potential to introduce innovation; someone who can be motivated to cooperate and can work with high or low morale and can develop feelings of resentment for the organization or pride at belonging to it. Taking care of people's motivations, and in general having a more complete view of the human being, are seen as important aspects of management. Control techniques are important but fostering creativity, motivation and good feelings are also very relevant. The title of a book published by David A. Emery in 1970 is quite pertinent: The Complete Manager. Combining the Humanistic and Scientific Approaches to the Management Job. The thesis is that managers should combine control with promoting good human attitudes of workers, should avoid stifling creativity, turning off motivation and igniting resentment and resistance (Emery 1970, p. ix).

One can argue this perspective, is still very narrow for $\mathrm{HM}$, since employees are exclusively seen as "human resources" for economic goals. However, we can support the idea that we need a more comprehensive view of the person, and gearter consideration of his or her different motivations and capacities.

As noted above, some scholars who advocate humanism in economic and business not only argue for a wide view of the human being but also emphasize the dignity of each person, the preeminence of people over material goods and the necessity of a new business paradigm. In this line of thought, Pirson and Lawrence (2010) proposed a humanistic view of business, highlighting how this differs from current 'economistic' conceptions.

Scholars involved in the humanistic management movement use the term humanistic management in different senses, often without a deep philosophical discussion of the term, and present partial meanings which may shed some light on the concept of HM. Thus, Arnaud and Wasieleski (2014) consider the core of a humanist management to be promoting selfdetermination at work. This entails treating employees with respect and focusing on their wellbeing, satisfaction, and self-actualization at work. The HMN define humanistic management as a management which submits business decisions to these three guiding principles on the basis of three interrelated dimensions: 1) humans deserve and rightfully expect our dignity to be respected under all circumstances, 2) ethical consideration must form part and parcel of business decisions, and 3) business should actively embrace the idea that corporate responsibility is contingent upon initiating and maintaining an ongoing dialogue with all stakeholders. They believe that these three dimensions in combination promote human well-being through economic activities that are lifeconducive and add value to society at large. (www.humanetwork.org)

This more comprehensive view of the human being also appears in Andreu and Rosanas (2012) in their rational and humanistic view for a better management. They stand for the necessity of a well-constructed management theory, with a concept of the human being as a whole person, a subject of rights and the end of any action, guided by purpose or intention, having bounded rationality and being a subject of learning (Andreu and Rosanas, (2012, p. 137-8). 
Dierksmeier (2011) argued that management theory should move towards a humanistic paradigm, centered on the idea of human dignity. Actually the recognition and respect of human dignity is presented as a crucial point of HM by many authors. In negative terms, Spitzeck labels as non-humanistic those business activities which are to the detriment of human dignity (2011 p. 55). Khan and Amann launched "a call for more humanism in the business world, which grants human dignity a center-stage position in the business world." (2013, p. 1).

According to Spitzeck, HM holds a new vision for business focused on "serving the societies in which business operates, increasing their citizens' quality of life" (2011, p. 51). Some authors point out companies which put HM into practice by focusing on social benefit rather than on profit maximization. In collective work edited by Kimakowitz et al. (2011a), which includes 19 case studies of companies that incorporate HM in practice, the editors suggest that "[o]ne general prerequisite for managing a business along with humanistic principles is the emancipation from a sole focus on maximizing profits." (Kimakowitz et al. (2011a, pp. 2-3). They also affirm: "What these companies share is that they are managed as an integrated and responsible part of the society" (p. 3). The raison d'être of these companies includes the promotion of social benefit. In addition, these companies reject profit maximization as a normative criterion and maintain the liberty to opt out of the application of market rationality where this would conflict with or decrease the social benefits (Ibid.)

Rodríguez-Luesma et al. (2014) see humanism (in management) as cosmopolitanism and as dialogue, on the basis of the inviolability of human dignity. The encounter with "the other" constitutes a reminder and a challenge to engage the other in a process of mutual discovery and dialogue in which one learns about others' values and about one-self. According to these authors: "Managers become humanistic when the dialogue in which they engage with stakeholders, beyond information and knowledge about the economic and technical aspects, entails learning about the other's system of values" and remembering that "every person's dignity is inviolable." (Rodríguez-Luesma et al. 2014: 87-8). On his part Alvira suggested that those who manage business with humanism should take each individual into account and be aware "that this one is neither a mere workforce nor a simple inalienable subject of rights, but pure and simple a human being, that is a brother or sister" (1992, p. 47).

Drawing from the Classics, I have defined HM as "a management that emphasizes the human condition and is oriented to the development of human virtue, in all its forms, to its fullest extent" (Melé 2003a, b, p.79). I still think that this is correct, although quite limited, since this account does not express sufficiently the richness of the concept.

This short review, which is by no means exhaustive, shows that there is not unanimous consent on what humanistic management means. However, these examples provide valuable insights which invite us to reflect on how genuinely humanistic management should be understood. Furthermore, most of the ideas presented by different authors are not incompatible but complementary. Thus, I suggest that many particular views of HM can be integrated in a more comprehensive vision of HM and, in addition, this composite can be enriched by some reflections on the human condition, helping us to seek a genuine notion of humanism and apply it to management. This is not an easy task, but an exploration can be attempted, and this is what we try to do next.

\section{Understanding Humanism}

Since at least the 19th century, the term "humanism" has designated the Renaissance emphasis on studying classical authors and languages (Latin and Greek) in education, and humanists are 
those who promoted such studies (Campana 1946). The importance of the human being acquired in this period derived to a notion of humanism with more substantive content, emphasizing knowledge and concern for everything related to the human person. This, broadly speaking, is the sense in which humanism is usually understood today.

In the Renaissance, humanistic authors such as Piccolo della Mirandola, Giordano Bruno, Thomas Moore, Luis Vives and Erasmus of Rotterdam, though they took different approaches, had in common a strong exaltation of the human in an often exaggerated contrast to the supremacy of the sacred in the Middle Ages. They generally had a reactionary posture against the intromission of clergy in topics which were not of their concern. All of these writers believed in God and God was a reference in their writings, at least implicitly, but many marginalized God to emphasize the human, while others adopted a more balanced position.

The diversity of approaches and understandings of humanism became deeper in the last two centuries, and expressions can be found such as Marxist humanism, Existentialist humanism or Christian humanism. Some notions of humanism include transcendence and human dependence on God. Others however, present humanism as being in opposition to or even in substitution of religion. Adherents of the former interpretation, hold that that dependence of God does not erode human dignity but even highlights it, while supporters of the latter not only defend the opposite position but also define humanism by the exclusion of all reference to the supernatural and by the denial of all transcendence.

The heterogeneity of understandings of humanism makes it difficult to present an unambiguous notion of humanism and consequently of humanistic management. However, beyond the evident differences, in every humanism there is a common concern for the human being. Two authors with a significant different background can ilustrate this point. Jean-Jacque Maritain -a Neo-Thomist thinker who has been quite influential in Christian humanismrecognizing that the definition of humanism can be developed along very different lines, suggested leaving the whole discussion on such definitions of humanism open, and proposed instead some essential features of humanism. He affirmed:

"[Humanism] trends essentially to render man more truly human, and to manifest the original greatness by having him participate in all that which can enrich him by nature and in history (...); it at once demands that man develop the virtualities contained within him, his creative forces and the life of reason, and work to make the forces of the physic world instruments of his freedom." (Maritain 1973, p. 153)

These words can be contrasted with others of Erich Fromm, associated with the Frankfurt School of critical theory. According to Fromm,

"[Humanism is] a system centered on man, his integrity, his development, his dignity, his liberty. On the principle that man is not a means to reach this or that end but that he is himself the bearer of his own end. Not only on his capacity for individual action, but also his capacity for participation in history, and on the fact that each man bears within himself humanity as a whole." (Fromm 1961, p. 147)

In spite of belonging to very different philosophical traditions, these two views seem complementary rather than contradictory and some agreements can be found. One of these regards concern for vulnerability of human beings and their innate rights; and, in positive terms, the promotion of human development. In this sense, as Pope John Paul II wrote, violation of human rights is "an incomprehensible manifestation of activity directed against man, which can in no way be reconciled with any program that describes itself as 
'humanistic'" (John Paul II 1979, n. 17). On the contrary, a humanistic approach requires that in any social, economic, political or cultural program the human being should be invariably brought to the fore (Ibid).

Seeking philosophical grounds of humanism in economics, Nida-Rümelin (2009) pointed out four mutually-dependent key elements of humanism. The first refers to the refinement of the given nature and the subsequent importance of education and learning. The second is the existence of reason and capacity of reasoning of all humans beings. Universalism is the third element of humanism, in the sense that humanism addresses all persons and there are no essential differences of ethnicity, nation, race, social status, or culture. The fourth element is that humanistic values address the individual, not the collective (Nida-Rümelin 2009, pp. 15-7).

In a very synthetic approach, Alvira affirmed that humanism simply "consists in taken the human being seriously" (1992, p. 42) and, in his opinion, this requires two aspects, which are not exclusive but complementary. One is to consider the human being as an absolute. Another is to see him or her as a whole." (Ibid.). Here, we propose extending this analysis through the following terms: 1) wholeness, 2) comprehensive knowledge, 3) human dignity, 4) development, 5) common good, 6) transcendence, and 7) stewardship-sustainability. We do agree with the two features mentioned by Alvira, which probably are essential, and the other five can be considered as derived from these, bearing in mind that the human being is an absolute and whole being. These seven features can be explained through the following propositions:

Proposition 1. Humanism recognizes the whole person, without reducing the human being to a few aspects (wholeness).

Concern for the human entails recognizing the whole person without reducing the human being to a few aspects. This contrasts with views of the human used in some mainstream economic and management theories in which the human being is only seen as a self-interested individual with preferences and rationality to maximize preferences (Ghoshal 2005) and also with others which only focus on psychological, sociological or political aspects of the human being (Melé and Gónzalez Cantón 2014, Chap. 2). The whole person -we could term it homo integralis - entails considering the human to have a variety of possible motivations; a wide rationality, beyond the utilitarian cost-benefit analysis; emotions, freedom, personality and character -shaped by moral traits-; capacity of learning, relationability and sociability, intentional interaction with natural environment; openness to transcendence, with spirituality and/or religiosity; capacity for moral discernment; and a deep tendency to personal growth, human flourishing and happiness (see. e.g., Melé and González Cantón 2014). The view of the person as a whole is not only demanded by scholars of humanistic management, as noted above, but it is present in most philosophical systems, cultures and religions.

Proposition 2. Humanism seeks a comprehensive knowledge of the human being and therefore is aware of the substantial specificity of all human beings due to the spiritual element-mind or soul-that distinguishes them from other animals, and the uniqueness of each person (comprehensive knowledge).

Comprehensive knowledge of the person and the specificity of the human being are closely related with the wholeness of the human being. Throughout history, different philosophers have noted the substantial specificity of all human beings compared with animals, in spite of a similarity in some aspects. Some stressed that this difference lies in the fact that human share 
"a rational principle" -in accordance with a popular dictum that man is "a rational animal" while others see this difference in freedom, in being a moral agent, i.e., having the ability to make moral judgments based on some notion of right and wrong, or on other related features of what generically is called mind or soul. Even the human body, in many respects, exhibits a form consistent with an animal that possesses reason. For instance, the face and eyes have an enormous capacity to communicate feelings, emotions and thoughts, and the structure of the human hand permits it to use many complex artifacts. Although it is a matter of debate, the mind or soul is something spiritual which uses the brain but which is not reducible to pure biopsychic mechanisms (Adler 1997, pp. 179-184)

Sharing "a rational principle" all humans have a common nature, which gives us an essential equality. But, at the same time, each individual is unique, possessing certain particularities equal only to oneself which no-one else has. This uniqueness entails not only a genetic heritage but also cultural influence and above all, a biography made up of personal decisions, which configure one's own personality and character.

Proposition 3. Humanism respects, protects and promotes the constitutive dignity of every human being and the innate rights associated with such dignity (human dignity).

Dignity denotes being worthy of honor or respect. In talking of human dignity we mean an inherent and immeasurable worth of each human individual, no matter the gender, race, nationality, ethnical precedence, religion, ideology or sexual orientation. In contrast with the dignity associated with a certain position in society, which can be lost -e.g., a judge that knowingly gives unjust sentences- human dignity is inherent and constitutive of the human condition.

The immeasurable worth of each human individual is accurately expressed by Kant by stating that the human being possesses a dignity by which he exacts respect for himself from all other beings in the world: things have price while persons have dignity. This differs from the position of Hobbes -a non-humanistic author- who believed that the value or worth of a man is, as with all other things, his price (Dillon 2015).

Although the human being is vulnerable, being easily hurt or harmed physically, mentally, or emotionally, and subject to many limitations, his or her dignity is an absolute which deserves personal respect, protection from others and promotion when such dignity is at risk or not respected. Blatant offences against human dignity are slavery, exploitation and manipulation of people, and also treating them as mere human resources or simply a source of income.

The absoluteness of human dignity is not in opposition to being dependent on God. On the contrary, as Alvira wrote: "Only if there is someone fully and eternally absolute can I understand I am absolute by birth. But there is such a Being, I must take seriously -with responsibility-considering others as absolutes." (Alvira 1992, pp. 43-44). Furthermore, theist positions, such as the Judeo-Christian tradition, are great supporters of human dignity (Novak 1998) one example being that, according to the Bible (1966) (Genesis 1:26-27), human beings have been created in the image and likeness of God.

Human dignity supports the existence of innate, universal, and inalienable human rights, which, like human dignity, deserve respect. Both respect for human dignity and rights have been highly influential within international law, national constitutions and applied ethics.

Proposition 4. Humanism sees the human being in permanent development and calls on him or her to flourish as a human. This is the responsibility of each person, but since the 
material, social and cultural environment can favor it, humanism seeks to foster the conditions for such flourishing including appropriate well-being (development).

Human beings, as with other living beings, grow but human growth is not only biological it is also intellectual -human reason is open to everything-, the volitive -reinforcing the will through the character-, and emotional -shaping feelings in one way or another. We are continuously learning from others, by reflection, and by acting. Through the latter we acquire skills and habits -stable dispositions of the character, which can include a moral content (virtues or vices, in the traditional terminology). We -wrote Aristotle- "become builders by building and lyreplayers by playing the lyre; so too we become just by doing just acts, temperate by doing temperate acts, brave by doing brave acts." (1980, II, 1).

Human flourishing is a complex concept related to human excellence (Frankell et al. 1999) and, according to some authors, rooted in human nature (Rasmussen 1999). Virtues are the quintessence of human flourishing (Cherry 2009) because they reinforce the noblest aspects of the human being, i.e., reason and will. We might usefully remember here that according to Aristotle, "virtue" is "excellence" ("arête" in Greek). He also termed virtue "hexis" (1980, II, 4), a Greek word which means an active condition -not a mere routine.

In some way, we feel called to know the truth and to seek the meaning of our existence and to love what we know is truly worthy. This is a calling to human flourishing, and the answer is a personal responsibility but other people and the environment have an influence and can make a positive contribution to human flourishing through education, communitarian activities and appropriate conditions of psychological well-being.

Proposition 5. Humanism emphasizes both individual freedom and sociability, and consequently is in favor of respecting free initiative, dialogue, participation, cooperation and oneness in social life -respecting diversity. Humanism works for living together harmoniously and pursuing the common good of all (common good)

The wholeness of the human being includes freedom but also relationability and sociability. Aristotle affirmed that "man is by nature a political [social] animal (zoon politikón)" (1943, I, 2), and added: "he who is unable to live in society, or who has no need because he is sufficient for himself, must be either a beast or a god." (Ibid.) We live in society and need others to develop themselves.

Relationability among human persons is expressed through a dialogue using the human capacity for language, including body language. It is not difficult to agree that persons are constitutively made for relation and dialogue with others. Sociability means our natural tendency to live in society and to establish bonds between the person and the social groups to whom we belong. Relation with others and with social groups is not only a necessity for achieving what we need from others, it is also a way to serve others and to give oneself, and so to flourish as human beings. Recognizing and fostering relationability and sociability is in line with humanism which, as noted above, considers the whole person and is in favor of human flourishing.

Humanism is in favor of respecting free initiative as an expression of freedom and diversity but also sees dialogue, participation and cooperation as expressions of sociability.

Living together in an ordered society requires respecting justice by giving to each one what is due (his or her right). There is no social cohesion and peace without justice, but justice is not the only bond among persons living together. We also establish other bonds, such as a sense of belonging, affection, compassion, and commitment. Benevolence in its genuine sense wanting good for others- goes beyond justice in human relations. 
In social life, people not only coexist individually; they also establish cooperative relationships. These can be purely for the ends of mutual interest, but also based on generosity or in a sense of friendly cooperation. Obviously, human beings do not always adopt friendly attitudes, and it can sometimes be true that "man is a wolf to other men" (homo hominis lupus est), as a well-known Latin proverb attributed to Plautus affirms. However, there is no evidence that this dictum is a perfect description of social human nature. Humans also perform generous acts of service in helping others. It seems more accurate, and therefore more humanistic, to say: "man is man to his fellow man, with all of his or her greatness and weakness of the human condition". Lucius Annaeus Seneca (s.d.) went further by considering "man, an object of reverence in the eyes of man" (homo, sacra res homini).

In any case, the opportunity of acting in a friendly manner can be considered as a key element to build society and one which goes beyond justice. "When men are friends they have no need of justice", wrote Aristotle (1980, VIII, 1), adding that "friendship seems to hold states together, and lawgivers care more for it than for justice; for unanimity seems to be something like friendship, and this they aim at most of all." (Ibid) This idea has been rendered in modern times with the notion of "civic friendship" (Healy 2011; Leontsini 2013). As this latter scholar argues, friendship between fellow citizens is important because it contributes to the unity of communities and of the state, by transmitting feelings of intimacy and solidarity. An attitude of civic friendship fosters the oneness in social life in pursuing the common good of all and contributes to living together harmoniously and in peace.

Proposition 6. Humanism, although it stresses the preeminence of the human beings, also shows respect for the identity, worth and interconnectivity of every living and for the whole of nature; it encourages people to act with a sense of stewardship, promotes harmony between humans and nature and a sustainable development of humanity (stewardship-sustainability).

Humanism defends the specificity of the human spirit and human dignity and consequently concedes preeminence to the human being over other material beings. However, this in no way means that humanism is a despotic anthropocentrism. On the contrary, it recognizes that each being has its own identity and worth and that there is interconnectivity of every living being and it encourages a respectful attitude toward all beings and toward the ecosystem.

In focusing on humans, humanism does not ignore the fact that the Earth is the common home of all humans but this home is also inhabited by other living beings. In the use of natural resources, it promotes a sense of stewardship. This seems in tune with the first article of the Rio Declaration of the United Nations on Environment and Development (UN 1992), which states: "Human beings are at the centre of concerns for sustainable development. They are entitled to a healthy and productive life in harmony with nature."

Humanism also cares about sustainable development, defined by the Brundtland Report (UN 1987), as "development that meets the needs of the present without compromising the ability of future generations to meet their own needs." This document (Conclusions) emphasizes "the essential needs of the world's poor, to which overriding priority should be given", and "limitations imposed by the state of technology and social organization on the environment's ability to meet present and future needs." Sustainable development includes three dimensions: economic, environmental and social. All of them are taken into consideration by humanism. 
Proposition 7. Humanism recognizes than humans are self-transcendent beings, seeking a meaning for their lives, and is respectful with religions and spiritual behaviors.

Some humanisms are not theistic while others are, but a full understanding of the human being cannot ignore the human openness to something or someone above the individual and the restlessness of the human spirit driven forward to something more beyond the self to find a meaningful sense of life. The well-known psychiatrist Viktor E. Frankl wrote: "I wish to stress that the true meaning of life is to be discovered in the world rather than within man or his own psyche, as though it were a closed system. I have termed this constitutive characteristic 'the selftranscendence of human existence.' It denotes the fact being human always points, and is directed, to something, someone, other than oneself - be it a meaning to fulfill or another human being to encounter" (2004, p. 115). The French thinker Blaise Pascal expresses the self-transcendence of the human being by saying: 'l'homme passe l'homme' (1962[1660], n. 131), that is, "man goes beyond or transcends himself'. We transcend ourselves when we attentively contemplate aspects of our existence such as the wonderful order of the cosmos, the inner experience of beauty and the existence of values, which we do not invent but find (Cottinghan 2012).

Human self-transcendence can be related to something or someone who transcends the individual -the Transcendent- for many is God or the divinity and from the discovery of God and the relation to Him emerge religions, which includes spirituality as meaningful activity of the soul connected with the sacred. Others, even those who are not religious, also search for something transcendent as blissful experience.

Although some humanisms have historically presented themselves in opposition to religions, as noted, since humanism is respectful with the human, it should be recognized that many people are religious or spiritual and show a respectful attitude toward religions and spiritual behaviors.

\section{Exploring Humanistic Ethos for Management}

There is a vast literature on management thought and practice developed mainly in the last century, which is not possible to present in a paper like this, even briefly. ${ }^{1}$ But in essence, as Peter Drucker (1990, p. 221) wrote "management is about human beings". This is, of course, quite simple, but much more comprehensive than another popular definition of management focused on results: "management regards getting results through people". More sophisticated, but also focused on results, is to say that "Management in businesses and organizations is the function that coordinates the efforts of people to accomplish goals and objectives by using available resources efficiently and effectively." (Wikipedia, search "Management") We might dare to suggest the more humanistic, "management is the art of getting things done with people coordinating their efforts and allocating resources (financial, technological, and natural resources) and knowledge in accordance with the institutional mission to accomplish goals."

What is relevant for our purpose here is that underlying management there is a certain ethos, which has been defined as "the distinguishing character, sentiment, moral nature, or guiding beliefs of a person, group, or institution." (The Merriam-Webster Dictionary ${ }^{2}$ ). In this sense, we can talk of a "humanistic ethos" in management when such management is embedded with the guiding ideas and values of humanism.

\footnotetext{
${ }^{1}$ For a short history of management see, e.g. Boyer and Equilbey (1990).

${ }^{2}$ http://www.merriam-webster.com/dictionary/ethos.
} 
We suggest that managing business entails an ethos, which includes at least four basic elements: 1) a conception of the individual and the human work, 2) a notion of the society and the role of the individual in the society and interacting with nature, 3) a view of the business firm and 4) an assumption of the purpose of business in society. These basic elements, understood in a humanistic sense, are four crucial pillars for a humanistic ethos for business management.

\section{Conception of the individual and the human work}

Humanistic management entails considering a vision of the individual such as that presented in the propositions enumerated above, including the consideration of the whole person, the universal human dignity and rights of each person and the continuous development or degradation that people experience due to organizational and working conditions. In short, the vision of the individual is that of a conscious and free being, endowed with intrinsic dignity.

Far from assuming the model of human individual as rational self-interested maximizer (the homo economicus model), humanistic management takes into account a number of human features that this model ignores (Melé and González Cantón 2012, pp. 17-24). In short, humans have a variety of motivations for acting and self-interest is not the only motivation for human behavior. Rationality has a wide meaning without reducing it to a calculative ability for cost-benefit analysis. Freedom is not merely absence of coercion on the individual when he or she exercises choice, but also and mainly the capacity of selfdetermination. Moral discernment, responsibility and accountability are intrinsic to the human being, while morality is alien to rational choice and the maximization of utility of the homo economicus. Learning by acting and personal development are important anthropological characteristics. The human being is a social being far from the idea of a radical individualism. Feelings and emotions should not be omitted, since they are seen as important aspects of the human condition.

The vision of the human work is also crucial in a humanistic ethos for management. According to Lutz and Lux (1988, p. 153), work is one of the most important topics in humanistic economics, however, "work occupies only a peripheral place in contemporary economics texts, where it is ordinarily referred to as 'labor' and analyzed as one of several inputs (or 'factors of production') in making consumable commodities and services." (Ibid.).

Human work contributes to both production and personal development, by acquiring both professional skills and moral virtues. Since work directly proceeds from the person, in a certain sense, shares the human dignity of the worker. Thus, work is much more than a commodity or anonymous force within the productive system (Tablan 2014).

Giving importance to the worker only as a factor of production does not do justice to human dignity and such humanism-let me insist-is, at best, reductionist and incomplete.

The recognition of and respect for human dignity and the calling to each person to flourish as a human being require dealing with people with justice, benevolence, and civic friendship, and the recognition of and respect for human openness to transcendence.

\section{The Notion of Society and the Role of the Individual in the Society and Interacting with Nature}

Political philosophers have, for years, been discussing the nature of the society and what kind of links unite individuals and the society. They have also been debating what a thing is a just society is (see, e.g., Brown, 1986). Some of these proposals tend to be very individualistic, without social 
glue or weakly united by interests and hypothetical "social contracts". Others, in constrast, assume that society is a great whole in which individuals are diluted and depersonalized and the collective prevails.

The humanistic notion of society is as an association of conscious and free people ruled by justice, benevolence and civic friendship, living together, acting with reciprocity and cooperation and so forming a whole, without losing their personality and sense of responsibilities. Persons share of the common goods of the society, such as good natural environment, social support, humanistic culture, means of communications, role models, and solidarity of others, and at the same time they contribute to the common good in some way. Society is not therefore a collective where persons are diluted and depersonalized. On the contrary, persons remain conscious and free individuals with the willingness to achieve common purposes.

Society are not only shaped by individuals, but also by intermediate associations created for specific purposes, which should contribute to a good society as a part of the whole.

This humanistic view is not a collection of disconnected people seeking individual interest without any concern for the whole. In this "atomistic view" of the society-ignoring human sociability-the only possible social integration comes from the existence of agreements or hypothetical social contracts to assure coexistence, while each pursues his or her own interests or sacrificies some of them for the sake of coexistence. The atomistic approach generally includes a functionalist view of each institution connected with particular interests or goals. Thus, business is responsible for making profits, unions for defending the worker's interest, schools for teaching, churches for worship, and so on. The State should be in charge of balancing interests and promoting the general interest. Rather than common good (good for all of us), there is a sum of particular interests or goods of the individual in the society.

The role of the individual in the society is to not only pursue his or her particular goods but also contribute to the common good of the society - not necessary in opposition to particular goods.

Regarding interaction with nature, humanism, as noted, is in favor of sustainability and stewardship. While respecting the preeminence of the human, it recognizes the identity and connectivity of all living beings and seeks to hamonize this with a fully respect for human dignity. Consequently, it adopts a responsible anthropocentrism in the use of natural resources, maintaining a clean environment, seeking harmony with nature and preserving the heritage for future generations.

\section{View of the Business Firm}

In establishing and managing a business firm different features of the human being concur, including the freedom to undertake business, hire and trade, the capacity to associate and to participate in a common endeavor to achieve certain goals.

Cooperation is an essential aspect for business, and cooperation needs communication, motivation, and leadership (Bernard 1968). Underlying these concepts there is the awareness of dealing with conscious and free beings who are endowed with human dignity. This is congruent with humanism as well as seeing the business firm as a human reality with the characteristics of a community of persons. Seeing the firm as a "community of persons" defends both the human freedom of people and their association to form a whole through a common goal and a multiplicity of links. As I tried to show elsewhere (Melé 2012), considering the business firm as a community of persons, where they can flourish, can be a pillar of a humanistic ethos. 
The humanistic view of the firm rejects the idea of the business firm as a mere aggregate of individuals united exclusively by contracts or the business firm (or the corporation) exclusively as an artificial creation of the law. This "atomistic view" ignores human relationability and sociability and the rich framework of relationships existing in the firm beyond contracts, including willingness to cooperate, mutual recognition and personal affection among peers, and moral links based on commitment and loyalty.

The firm, rather than a collection of individuals and an artificial person or agent, is a real entity, a whole. However, this idea can lead us to see the firm as an organism. This is the socalled "organic view" of the firm. Humanism also rejects the "organic view", where persons have little or no autonomy within the severely depersonalized social organization. With this perspective, personality, personal initiative and sense of responsibility may be lost, which would be to lack respect for human dignity.

The firm, in essence, is a community, and communities can be be built up through the sense of belonging, the awareness of common purposes, the links among those who form the community and the willingness to cooperate for achieving common goals.

\section{Purpose of Business in Society}

Another crucial point of the humanistic ethos for managing business is the purpose of the business in society - different from subjective motives for undertaking business. The purpose of business along with the means used to achieve it is what gives moral legitimacy to business.

The humanistic view recognizes that business is born in the society, is part of the society and the receptor of its activity is the society. Its moral legitimacy should come from contributing to the common good of the society. This happens in providing goods and services fairly and efficiently, maintaining and creating jobs that they are consistent with human dignity and appropriate to fostering human flourishing, manintaining humanistic relations with stakeholders, and generating wealth. Each business carries out this generic purpose in accordance with its specific mission, and by acting as a corporate citizen, always with coherence with the common good. Providing reasonable returns for investors is one of the ends of the firm, but the purpose of the firm entails higher ends than making money.

In this way, business enriches society, where enrichment is understood in a broad sense. Solomon expressed this idea by saying: "the purpose of business is to do what it has always been meant to do, enrich society as well as the pockets of those who are responsible for the enriching (1992, p. 180-181)."

The purpose of the business firm has to be achieved by fair means and with respect for the ecological requirements, including those derived from both natural and human ecology.

The humanistic vision of individuals recognizes property rights but with an associated social responsibility. This differs from other positions that consider property rights are almost absolute and the business firm is seen as a society of capitals with the exclusive purpose of benefiting shareholders. Here, business management would have no other social responsibility than producing profits for shareholders, with the only limitation of being to respect the law and the rules of fair competition (Milton Friedman 1962, 1970). One not-too-different alternative is to present the purpose of the firm and the responsibility of managers as to maximize shareholder value and to accept that satisfying stakeholder interests is acceptable if it contributes to improve the bottom line (Jensen 2001).

The 'stakeholder approach' (Freeman 2004) sees the purpose of the firm in satisfying the interests of the stakeholders of the firm (shareholders, employees, customers, suppliers, and 
local communities, and often others), or creating value for them. This vision is closer to humanistic vision, although the relationships between the firms and its stakeholders are exclusively based on interests, and so it seems an individualistic view of society.

\section{Outline for the Practice of Humanistic Management}

As established by Henri Fayol (1984[1916]), one of the pioneers of management thought, management includes a number of functions, ${ }^{3}$ which nowadays are usually described as planning, organizing, staffing, leading or directing, and controlling. From a different perspective, Henry Mintzberg, based on detailed research and thoughtful observation, pointed out ten roles of the manager grouped in three basic categories. The first group refers to interpersonal roles, which involve coordination and interaction with employees, performing symbolic duties as a representative of the organization (figurehead), establishing the atmosphere and motivating the subordinates (leader), and developing and maintaining webs of contacts outside the organization (liaiser). The second group is of informational roles that involve collecting all types of information that are relevant and useful to the organization (monitor), transmitting information from outside the organization to those inside (disseminator), and transmitting information from inside the organization to outsiders (spokesman). The third group are roles which entail decision-making; they include initiating change and adapting to the environment (entrepreneur), dealing with unexpected events (disturbance handler), deciding on the use of organizational resources (resource allocator), and negotiating with individuals and dealing with other organizations (negotiator) (Mintzberg 1973).

Apart from the managerial ethos there are a number of practices, described by Fayol (19841916) and Mintzberg (1974) as noted above, which can be reformulated through seven key managerial practices, each of which can be embedded with humanistic principles.

1) Creation of institutional statements, including corporate values (what we value most), mission (what we do) and vision (what we want to become). Institutional statements, frequently rooted in the foundational ideas of the company are often a solid and permanent element of the business firm and a crucial guideline for management. HM combines humanistic values with technical and strategical elements in the creation of institutional statements.

2) Formulation of strategies, objectives and plans for action. These practices entail establishing (top managers) or following (middle managers) the goals to achieve frequently under conditions of uncertainty, foreseeing what could happen in the future and planning whatever might be require to attain the desired ends. In these formulations, it is important to give an accurate diagnosis of the situation and an accurate evaluation of people and resources to execute the actions and to achieve the goals. To this end, Andrews (1987) recommended deliberating about the strengths and weaknesses of the firm and opportunities and threats of the environment. From the diagnosis and under the guidelines of corporate values, mission and vision, the strategy, objectives and plans of action, management seeks the best adaption to each external environment or competitor of the organization. HM considers not only economic, political or technical goals but also the

\footnotetext{
${ }^{3}$ According to Fayol (1984[1916]), management operates through five basic functions: planning, organizing, coordinating, commanding, and controlling.
} 
human, social, and environmental impacts of achieving such goals and how to respect human dignity and foster human flourishing in determining the means to achieve them. The goals for management can include strengthening the organization by building talents and helping people to overcome their weaknesses. The task of management is "to make their [of people] strengths effective and their weaknesses irrelevant (Drucker 1990, p. 221). This is particularly relevant for HM.

3) Organization and structure. Strategy and other goals require as means organization of people and allocation of material resources through an appropriate structure. An organizational structure defines a certain organizational chart or specific roles or responsibilities for people within the organization, policies, proceeds, coordination, supervision and allocation of raw material, technology, information, and financial funds. The configuration of the structure can adopt a multiplicity of forms regarding hierarchy, specialization, formalization, standardization, centralization, flexibility and architecture. There is not an ideal humanistic organizational structure, but HM requires maximum respect for people, full consideration of their dignity and the development of persons within the organizational structure. The minimum humanistic requirement is to avoiding treating people as mere orders receptors, without any opportunity to show initiative, giving suggestions and participate.

In positive terms, HM encourages organizational structures in which people can develop themselves, respect for initiative within the common goals of the organization, and participate in accordance with the circumstances of each organization.

4) Coordination and control. Organizational structure is not everything when seeking to achieve the proposed aim or the organizational or partial targets. Modern businesses may have a great complexity especially when the size, scope functional specialization and departmentalization increase. This requires integration of disparate elements and management is key to accomplishing the unification, synchronization and harmonization to produce a complete or congruent outcome. A crucial aspect of the managerial task is the integration of people, and for this purpose, managers should take into account the fact that people are conscious and free beings and therefore simply giving orders is not enough to produce the desired coordination. HM also leads giving explanations and motivating those who have to be coordinated.

Another managerial task, which is not completely alien to coordination is control. Controlling is checking progress against plans. Through control managers influence other members of the organization to implement the organization's strategies (Anthony 1988). This influence should take place in such a way as to produce 'goal congruence', i.e., when managers pursue their personal goals at the same time they pursue the organizational goals (Cugueró-Escofet and Rosanas 2016). However, when a conflict between particular interests and the common good arises, the latter should prevail over the former (see Proposition 5). In the early days (period) of management thought, control was understood as strict compliance with plans in terms of time and quality and within a budget. Today control has become a quantitative evaluation of performance measured against the bottom line. According to Cugueró-Escofet and Rosanas (2016), in both theory and practice the latest control systems have gone in a direction of becoming more "automatic" in applying systems of measurement and incentives as substantial means of control, and pay less attention to qualitative aspects, with the consequence of dysfunctional effects, including some recent scandals.

5) Communication. This is a recognized managerial task closely related to the structure but beyond. There are formal communication processes, and channels, but managers express 
or exchange information or transmit their own thoughts, values and feelings in a variety of informal ways using words, sounds, letters, articles, videos, signs and a rich variety of social network media. Dissemination of manager decisions and the day-to-day behavior are also relevant messages to the organization. Avoiding lies and manipulative information is the first and most important ethical and humanistic requirement; the opposite would entail a lack of respect for human dignity. But HM also requires truthfulness in all communications, transparency in whatever is required and communicating humanistic values through words but especially by acting as humanistic role models.

6) Decision-making. Managers are continuously making decisions, both big and small. In a certain sense decision-making is the quintessence of management. Decision-making is a process which starts with the perception of a need to define the nature of the issue or problem which should be addressed or solved and the goal to be achieved with the decision. The human dimension is present in this first stage as the consideration of how the needs, issue or problem affects people. Then, the decision-maker should generate alternatives to reach the goal identified and evaluate these in accordance with appropriate criteria. HM is not limited to technical or economic or possible social reactions, but includes ethical and human evaluation, which can lead one to reject some alternatives and lean in favor of others. The next two stages involve choosing an alternative or course of action and implementing it. HM does not advocate taking the maximization of profits or the short-term maximization of the share price as a supreme criterion. Obtaining benefits and creating economic value is a relevant criterion but it should be balanced with other criteria giving primacy to humanistic values in the case of conflict with economic value. However, in the long term such conflict may disappear due to the trust, confidence and reputation which HM might generate.

7) Leadership. There are multiple definitions of leadership but in one way or another, they refer to influencing or motivating others for a common task. Thus, Northouse, a recognized expert in leadership, defines it as "a process whereby an individual influences a group (...) to achieve a common goal" (2001, p. 3). Setting clear common goal and determining what must be done in each situation and getting people to do it are tasks of management. A humanistic approach to leadership is far from both the old "bosssubordinate" model in which the power is applied over others, and from forms of paternalistic leadership in which collaborators are not treated as adults. In both cases the human condition of being a conscious and free being is ignored and this ultimately denotes a lack of respect for human dignity. In contrast, humanistic leadership requires an interactive relationship and dialogue between the leader and his or her followers and the concern of the leader for the followers' needs and personal growth and, at the same time, awareness of what is required for the community.

\section{Conclusion}

The increasing literature on humanistic management suggests the need for a review of the origin of the concept and the different meanings that scholars give to it. We found that in spite of evident differences most of these interpretations generally are not incompatible but complementary. They have in common their defense of a management oriented toward people while seeking profits for higher human ends. This contrasts with other types of management essentially oriented toward profits, where people are seen as mere resources for this goal. 
Actually, the approaches studied suggest the necessity of developing a more comprehensive view of HM. In turn, this requires a better understanding of humanism. Here the task is more complicated, as noted, since there are different ideologies which use the label "humanistic" but are quite different. This is the case of Existentialist humanism, Marxist humanism and Christian humanism. Nevertheless, all humanisms share concern for the human and human aspects of human activity.

Drawing from this common agreement, the previous humanistic management review, and personal reflection, we have presented seven propositions for humanism, with the purpose of providing grounds for humanistic management. These include taking into account the wholeness of the person and a comprehensive knowledge of the human being; the recognition and respect of human dignity and the calling to each person to flourish as human being, which requires serving others and the community; the centrality of the common good, which entails the necessity to act with justice, benevolence, and civic friendship; the human openness to transcendence; and the recognition of the identity and worth of other material beings, along with a sense of stewardship and sustainability.

Trying to apply these ideas to management, we have proposed four key elements for a humanistic ethos as a driver of HM. The first is seeing the person as a conscious and free being, endowed with dignity and called to flourish as a human being. The second views society as an association of people ruled by justice, benevolence and civic friendship.; the third is seeing the business firm as a community of persons, to be built up by reinforcing the sense of belonging, the awareness of common purposes, the links among those who form the community and the willingness to cooperate to achieve common goals. The fourth regards to purpose of the firm in society, which is that each firm contributes to the common good in accordance with its specific mission, and by acting as a corporate citizen.

Finally, we have outlined several aspects for the practice of HM, including the creation of institutional statements (corporate values, mission and vision); formulation of strategies, objectives and plans for action, organization of people and allocation of material resources through an appropriate structure; activities of coordination and control; formal and informal communication, decision-making, and leadership. Hopefully, these areas will be a matter for future research of a management oriented towards persons and with concern for the best results, but considering the latter as an instrument to serving persons and not the reverse.

\section{References}

Abela, A.V. 2001. Profit and more: Catholic social teaching and the purpose of the firm. Journal of Business Ethics 31, Part 2(2): 107-116.

Abela, A.V. 2014. A catechism for business: tough ethical questions and insights from Catholic teaching. Washington, D.C.: Catholic University of America Press.

Acevedo, A. 2012. Personalist business ethics and humanistic management: insights from Jacques Maritain. Journal of Business Ethics 105(2): 197-219.

Adler, M.J. 1997. Aristotle for everybody. New York: Simon \& Schuster.

Aktouf, O. 1992. Management and theories of organizations in the 1990s: toward a critical radical humanism? Academy of Management Review 17(3): 407-431.

Alford, H.J., and M.J. Naugthon. 2001. Managing as if faith mattered. Christian social principles in the modern organization. Notre Dame: Notre Dame University Press.

Alvira, R. 1992. ¿Qué es el humanismo empresarial? In El humanismo en la empresa, ed. A. Llano, R. Alvira, T. Calleja, M. Bastons, and C. Martinez Esteruelas, 33-47. Madrid: Rialp. 
Amann, W., M. Pirson, C. Dierksmeier, E. von Kimakowitz, and H. Spitzeck. 2011. Business schools under fire: humanistic management education as the way forward. New York: Palgrave-MacMillan.

Anderson, C. 1997. Values-based management. Academy of Management Executive 11(4): 25-46.

Andreu, R., and J.M. Rosanas. 2012. Manifiesto for a better management. A rational and humanist view. In Towards a new theoy of the firm. Humanizing the firm and the management profession, ed. J.E. Ricart and J.M. Rosanas, 109-150. Madrid: Fundación BBVA.

Andrews, K.R. 1987[1971]. The concept of corporate strategy. Homewood: Dow Jones-Irwin.

Anthony, R.N. 1988. The management control function. Boston: The Harvard Business School Press.

Arandia, O.and L. Portales. 2015. Fundamentos de la Gestión Humanista: Una Perspectiva Filosófica (Underpinnings of Humanistic Management: A Philosophical Approach). Ad-minister:26, 123-47.

Argandoña, A. 2003. Fostering values in organizations. Journal of Business Ethics 45(1/2): 15-28.

Aristotle 1943. Politics. Trans. Benjamin Jowett. New York: The Modern Library. Available at. http://classics. mit.edu/Aristotle/politics.html.

Aristotle 1980. The nicomachean ethics. Oxford - New York: Oxford University Press. First published in 1925.

Arnaud, S. 2008. Management humaniste: enjeux, outils et obstacles. Revue Internationale de Psychosociologie 14(34): 207-224.

Arnaud, S., and D. Wasieleski. 2014. Corporate humanistic responsibility: social performance through managerial discretion of the HRM. Journal of Business Ethics 120(3): 313-334.

Bainbridge, S.M. 2003. Catholic social thought and the corporation. Research Paper No. 03-20 School of Law, Research Paper Series, University of California, Los Angeles.

Beaudreau, B.C. 2012. A humanistic theory of economic behavior. The Journal of Socio-Economics 41(2): 222-234.

Boyer, L., and N. Equilbey. 1990. Histoire du management. Paris: Éditions d'Organisation.

Campana, A. 1946. The origin of the word 'Humanist'. Journal of the Warburg and Courtauld Institute 9: 60-73.

Cherry, M.J. 2009. The normativity of the natural: human goods, human virtues, and human flourishing. Dordrecht: Springer.

Cima, L.R., and T.L. Schubeck. 2001. Self-interest, love, and economic justice: a dialogue between classical economic liberalism and Catholic social teaching. Journal of Business Ethics 30(Part 1:3): 213-231.

Clark, C.M.A. 2004. Bringing realism to management education: contributions from catholic social thought. Review of Business 25(1): 6-14.

Cornwall, J.R., and M.J. Naughton. 2003. Who is the good entrepreneur? An exploration within the Catholic social tradition. Journal of Business Ethics 44(1/2): 61-75.

Cortright, S.A., and M. Naugthon. 2002. Rethinking the purpose of business. Interdisciplinary essays from the catholic social tradition. Notre Dame: Notre Dame University Press.

Cottinghan, J. 2012. Human nature and the transcendent. In Human nature. Royal institute of philosophy, supplement 70 pp. 233-54, ed. C. Sandis and M. Cain. Cambridge: Cambridge University Press.

Cugueró-Escofet, N. and J.M. Rosanas. 2016. The ethics of metrics: overcoming the dysfunctional effects of perfomance measurements through justice. Journal of Business Ethics, Forthcoming.

Cunningham, M.E., and N. Tichy. 1983. Planning for humanism. Journal of Business Strategy 3(4): 87-90.

Daley, D.M. 1986. Humanistic management and organizational success: the effect of Job and work environment characteristics on organizational effectiveness, public responsiveness, and Job satisfaction. Public Personnel Management 15(2): 131-142.

De George, R.T. 2006. The history of business ethics. In The accountable corporation. Vol 2 business ethics: 4758, ed. M.J. Epstein and K.O. Hanson. Westpoint: Praeger.

Dierksmeier, C. 2011. Reorienting Management Education: From the Homo Economicus to Human Dignity. Humanistic Management Network, Research Paper Series No. 13-05, Available at SSRN: http://ssrn. com/abstract=1766183 or http://dx.doi.org/10.2139/ssrn.83. Retrieved on March 28, 2016.

Dierksmeier, C., and M. Pirson. 2010. Freedom and the modern corporation. Philosophy of Management 9(3): 525.

Dierksmeier, C., W. Amann, and E.V. Kimakowitz. 2011. Humanistic ethics in the age of globality. PalgraveMacMillan.

Dillon, R.S. 2015. Respect. In The Stanford encyclopedia of philosophy, ed. E.N. Zalta. http://plato.stanford. edu/archives/fall2015/entries/respect/. Retrieved on March 28, 2016.

Drucker, P. 1990. The new realities. London: Mandarin.

Emery, D.A. 1970. The complete manager. Combining the humanistic and scientific approaches to the management Job. New York: Mc Graw-Hill.

Fayol, H. 1984/1916. General and industrial management. Preface of L. Urwick London: Pitman.

Follett, M.P. 1941. Dynamic administration. In The collected papers of Mary Parker Follett, ed. Henry C. Metcalf and L. Urwick. New York: Harper \& Brothers.

Frankell, E., F. Miller, and J. Paul. 1999. Human flourishing. Cambridge: Cambridge University Press. 
Frankl, V.E. 2004. Man's search for meaning. An introduction to logotherapy. London: Random House / Rider.

French, W.L., and C.H. Bell Jr. 1984. Organization development behavioral science interventions for organization improvement. Englewood Cliffs: Prentice Hall.

Fromm, E. 1961. Marx's concept of man. New York: Frederick Ungar.

Ghoshal, S. 2005. Bad management theories are destroying good management practices. The Academy of Management Learning and Education 4(1): 75-91.

Ghoshal, S., and C.A. Bartlett. 1997. The individualized corporation: a fundamentally new approach to management. New York: HarperBusiness.

Ghoshal, S., C.A. Bartlett, and P. Moran. 1999. A new manifesto for management. Sloan Management Review 40(3): 9-20.

Gómez Pérez, R. 1977. El humanismo marxista. Madrid: Rialb.

Healy, M. 2011. Civic friendship. Studies in Philosophy and Education 30(3): 229-240. doi:10.1007/s11217011-9221-3.

Herzberg, F. 1968. One more time: How do you motivate employees? Harvard Business Review 46(1): 53-62.

John Paul II. 1979. Encyclicla Letter 'Redemptor Hominis'. Available at http://w2.vatican.va/content/john-paulii/en/encyclicals/documents/hf_jp-ii_enc_04031979_redemptor-hominis.html. Retrieved on March 28, 2016.

Khan, S. and W. Amann. 2013. World humanism. Cross-cultural perspectives on ethical practices in organizations. Palgrave.

Kimakowitz, E.V., M. Pirson, H. Spitzeck, C. Dierksmeier, and W. Amann. 2011a. Humanistic management in practice. Houndmills: Palgrave-MacMillan.

Kimakowitz, E.v., H. Spitzeck, M. Pirson, C. Dierksmeier, and W. Amann. 2011b. Introducing this book and humanistic management. In Humanistic management in practice: 1-12, ed. E.v. Kimakowitz, H. Spitzeck, M. Pirson, C. Dierksmeier, and W. Amann. New York: Palgrave Macmillan.

Kleinfeld, A., S. Cludts, and D. Mele. 2003. Sustaining humanity, beyond humanism:editorial introduction. Journal of Business Ethics 45: 1-2.

Leo XIII. 1891. Encyclical-Letter 'Rerum Novarum' http://www.vatican.va/holy_father/leo xiii/encyclicals/documents/hf_1-xiii_enc_15051891_rerum-novarum_en.html. Retrieved on March 28, $201 \overline{6}$.

Leontsini, E. 2013. The motive of society: Aristotle on civic friendship, justice, and concord. Res Publica 19(1): 21-35.

Lilienthal, D.E. 1967. Management: a Humanist Art. New York: Carnegie Institute of Technology.

Linkletter, K.E., and J.A. Maciariello. 2011. Drucker's lost art of management: peter Drucker's timeless vision for building effective organizations. New York: McGraw-Hill.

Llano, A., R. Alvira, T. Calleja, M. Bastons, and C. Martinez Esteruelas. 1992. El humanismo en la empresa. Madrid: Rialp.

Lupton, N.L., and M. Pirson. 2014. Humanistic perspectives on international management. Houndmills: Palgrave- MacMillan.

Lutz, M.A., and K. Lux. 1979. The challenge of humanistic economics. Menlo Park: Benjamin/Cummingd.

Lutz, M.A., and K. Lux. 1988. Humanistic economics. The new challenge. New York: The Bootstrap Press.

Maciariello, J.A. 2014. A year with Peter Drucker: 52 weeks of coaching for leadership effectiveness. New York: Harper Collins.

Maritain, J. 1973/1936. Integral humanism. Notre Dame, IN: University of Notre Dame Press. Original: L'humanisme intégral (Aubier, París, 1936).

Melé, D. 2003a. The challenge of humanistic management. Journal of Business Ethics 44(44): 77-88.

Melé, D. 2003b. Organizational humanizing cultures: Do they generate social capital? Journal of Business Ethics 45(1/2): 3-14.

Melé, D. 2009. Current trends in humanism and business. In Humanism in business - state of the Art. A reflection on humanistic values in today's business world: 123-38, ed. H. Spitzeck, W. Amann, M. Pirson, S. Khan, and E.v. Kimakowitz. Cambridge: Cambridge University Press.

Melé, D. 2012. The firm as a "community of persons": a pillar of humanistic business ethos. Journal of Business Ethics 106(1): 89-101.

Melé, D. 2013. Antecedents and current situation of humanistic management. African Journal of Business Ethics 7(2): 10-19.

Melé, D., and C. González Cantón. 2014. Human foundations of management. Understanding the homo humanus. New York: Palgrave-MacMillan.

Melé, D., and C. Dierksmeier. 2012. 'Human development in business. Values and humanistic management in the in the encyclical «Caritas In Veritate».' 260. New York: Palgrave.

Melé, D. and M. Schlag. 2015. Humanism in Economics and Business. Perspectives of the Catholic Social Tradition. Dordrecht, Heidelberg, Germany: Springer. 
Meltzer, H., and F.R. Wickert. 1976. Humanizing organizational behavior. Springfield: Thomas.

Mintzberg, H. 1973. The nature of managerial work. Englewood Cliffs: Prentice-Hall.

Mire, J. 1976. Humanizing the workplace. Labor Studies Journal 1(2): 219-223.

Nida-Rümelin, J. 2009. Philosophical grounds of humanism in economics. In Humanism in business: 15-25, ed. H. Spitzeck, M. Pirson, W. Amann, S. Khan, and E. von Kimakowitz. Cambridge: Cambridge University Press.

Novak, M. 1998. The Judeo-Christian foundation of human dignity. Journal of Markets \& Morality 1(2): 107121.

Pascal, B. 1962 [1660]. Blaise Pascal, Pensées. Edited by ed. L. Lafuma. Paris: Editions du Seuil.

PCJP (Pontifical Council for Justice and Peace). 2004. Compendium of the social doctrine of the church. Città del Vaticano: Libreria Editrice Vaticana). Also available in: http://www.vatican.va/roman_curia/pontifical councils/justpeace/documents/rc_pc_justpeace_doc_20060526_compendio-dott-soc_en.html. Retrieved on March 28, 2016.

Pfeffer, J. 1998. The human equation: building profits by putting people first. Boston: Harvard Business School Press.

Pirson, M., and E.v. Kimakowitz. 2014. Towards a human-centered theory and practice of the firm. Presenting the humanistic paradigm of business and management. Journal of Management for Global Sustainability 2(1): $17-48$.

Pirson, M., and P. Lawrence. 2010. Humanism in business - towards a paradigm shift? Journal of Business Ethics 93(4): 553-565.

Plas, J.M. 1996. Person-centered leadership: an American approach to participatory management. Thousand Oaks: Sage Publications.

Rasmussen, D.B. 1999. Human flourishing and the appeal to human nature. Social Philosophy \& Policy Foundation.

Ricart, J.E., and J.M. Rosanas. 2012. Towards a New theory of the firm. Humanizing the firm and the management profession. Madrid: Fundación BBVA.

Rocha, H., and R. Miles. 2009. A model of collaborative entrepreneurship for a more humanistic management. Journal of Business Ethics 88(3): 445-462.

Rodríguez-Luesma, C., A. Davila, and M. Elvira. 2014. Humanistic leadership as a value-infused dialogue of global leaders and local stakeholders. In Humaistic perspectives on international management: 81-91, ed. N.C. Lupton and M. Pirson. Houndmills: Palgrave- MacMillan.

Rosanas, J. 2008. Beyond economic criteria: a humanistic approach to organizational survival. Journal of Business Ethics 78(3): 447-462.

Sandelands, L. 2009. The business of business is the human person: lessons from the catholic social tradition. Journal of Business Ethics 85(1): 93-101.

Seneca, L.A. s.d. Epistulae morales ad Lucilium. The Latin Library, http://www.thelatinlibrary.com/sen/seneca. ep14-15.shtml. Retrieved on 28 March 2016.

Spitzeck, H. 2011. An Integrated Model of Humanistic Management. Journal of Business Ethics, 99(1): 51-62.

Spitzeck, H., M. Pirson, W. Amann, S. Khan, and E. von Kimakowitz. 2009. Humanism in business. Cambridge: Cambridge University Press.

Spitzeck, H., M. Pirson, E. von Kimakowitz, and C. Dierksmeier. 2010. The humanistic management network. Zeitschrift für Psychologie 218(4): 246-248.

Swart, J.C. 1973. The worth of humanistic management: some contemporary examples. Business Horizons 16(3): 41-50.

Tablan, F. 2014. Ethical implications of catholic social teachings on human work for the service industry. Journal of Religion and Business Ethics 3: art. 11. Available at: http://via.library.depaul.edu/jrbe/vol3/iss1/11.

Taylor, F.W. 1911. The principles of scientific management. New York: Harper.

The Holy Bible. 1966. New revised standard version (catholic edition). Princeton: Scepter.

UN (United Nations). 1987. Report of the World Commission on Environment and Development: Our Common Future. http://www.un-documents.net/wced-ocf.htm Retrieved on March 28, 2016.

UN (United Nations). 1992. Río Declaration on Environmental and Development. http://www.un. org/documents/ga/conf151/aconf15126-1annex1.htm/ Retrieved on March 28, 2016.

Wolf, W.B. 1974. The basic Barnard: an introduction to Chester I. Barnard and his theories of organization and management. Itaka: New York State School of Industrial and Labor Relations - Cornell University.

Zigarelli, M.A. 1993. Catholic social teaching and the employment relationship: a model for managing human resources in accordance with Vatican Doctrine. Journal of Business Ethics 12: 75-82. 